\title{
Black Art: An Aesthetic Transformation for Freedom and Justice
}

\author{
Lekha Nath Dhakal, Ph.D. ${ }^{1}$
}

\begin{abstract}
This paper attempts to explore African Americans' world view and its roots in Black Aesthetics. It also reveals that Black art is an aesthetic transformation of African Americans for freedom and an expectation of a higher level of life. Supporters of Black Aesthetics appealed to black artists to establish a new standard of judgment and beauty based on African myths, spirituality, belief systems and music in opposition to Western aesthetic. However, the Black Aesthetics had its origins in those first artistic resonances of black slaves in the form of spirituals, coded singing and signifying, and later in writings. Black aesthetic theory in the United States traces its origin to the literature of slavery and freedom. The slave narratives depict African-Americans' artistic and academic labors to show their humanity and critical moments in the development of Black aesthetics. Writing about their own communities in order to establish a sense of self-worth and claiming their identities as African Americans are crucial elements in the works of many Black writers.
\end{abstract}

Key words: Harlem Renaissance, Black Aesthetics, Racism, Nationalism, Humanity

The Harlem renaissance was an outburst of black cultural consciousness that found its voice in various artistic expressions such as poetry, fiction, music, theater, painting, and sculpture. This achievement highlights the determination of African-Americans to encourage an aesthetic that concerns the socio-political experience. Although the Harlem Renaissance was primarily a literary movement, it served as a form of resistance and a social rejection of racism and shaped the socio-political nature of black works of arts. It pointed to the possibility of an aesthetic theory that mirrors the social justice conditions and actions of men. Black art work was an image of the right or wrong actions of man and offered a critical moment in Black aesthetic history.

The social factor that influenced the emerging Renaissance was a titanic journey of African-Americans from south to north. The movement was due to both practical and political concerns. It was an important part of the big industrial and social problems of

1 Dr. Dhakal is an Associate Professor of English at Nepal Commerce Campus, Minbhawan, Kathmandu, T. U. 
the democracy of that time. The north offered enough jobs for blacks. Alain Locke states in The New Negro, "with each wave of movement, the Negro becomes more and more a mass movement toward a larger and more democratic chance" (6). It is the notions of collective consciousness of blacks to develop a concept of nationalism. Building a theme of nationalism was a means for opening democratic possibilities for Black Americans. He employs art with the specific motivation towards recording the nature of sociopolitical rise and psychological uplift of the Black American. He believes that nationalism could be achieved through cultural pluralism and in the notion of social and cultural mutuality as well as in understanding the relativeness of values. He believes that these ideas can "prosper in an atmosphere of intellectual democracy" (201).

Locke's idea of cultural nationalism characterizes an existence of social mutuality in all standards - social, economic, and aesthetic between White Americans and Black Americans. Locke states, "the purpose of the work was to document the New Negro culturally and socially to register the transformations of inner and outer life of the Negro in America that have so significantly taken place in the last few years" (xv). W. E. B. Dubois asserts that the plays of the real Negro theater must be:

"About us.... they must have plots which reveal Negro life as it is, by us. That is, they must be written by Negro authors who understand from birth and continual association just what it means to be Negro today, for us; that is, catering mainly to Black audiences and near usthat is, in a Black neighborhood, near the masses of ordinary Negro people". (295)

Dubois advocates a propagandistic approach to Black art. He believes that the best message for black artist to convey is one of uplift.

The Black Arts Movement of 1960s was a period of literary and artistic growth among Black Americans. This stage of Black aesthetics has its history deep-seated in the political climate of social change in 1960s and 1970s. The Civil Rights Movement was a time of intensified struggle. The idea of equality crossed into every aspect of Black American life. Black aesthetics of 1960s and 1970s extended the Harlem Renaissance project toward a system of evaluating the creative works of Black people, which mirrored the character of the Black experience. Many black artists voiced against this tradition and embarked on a project to create a system to evaluate black art.

The Eurocentric look in the form of aesthetic judgment caused a psychological setback to the African-American artist, as Locke indicates a psychology of lowliness prior to the New Negro Movement when he states, "The Negro mind . . . is shaking off the psychology of 
imitation and implied inferiority" (10). Somewhere during the course of this history, the Black American mind had skidded back into psychological submission and was in need of an epiphany, or the - psychology of lowliness had not been completely — shaken off as Locke claims. The Black Arts Movement made an effort to forward a philosophy of Blackness, it proved more often to be an over generalized or theory of Blackness.

The 1960s was a period of political and civil disorder in America. Black Americans were not only in search of civil rights and freedom but also in need of an identity that was autonomous of mainstream perceptions and ideologies. Black intellectuals were in search of more effective means and methods of seizing power. Black writers turned away from the traditional themes and "journeyed toward a Black aesthetic" (Fuller 5). For Fuller, the revolutionary Black author had decided that White racism would no longer exercise its control over his work and that he or she would no longer separate literature from reality. "The world of the Black outsider, however much it approximates and parallels and imitates the world of the White insider, by its very nature is inheritor and generator of values and viewpoints which threaten the insiders" (7).

H. R. Madhubuti advocated for Black art that is directly connected to the daily lives of Black people. He articulated that he was racially and culturally motivated and quite deliberate in his writing, particularly in terms of employing the Afro American language. He argues that black poets deal in the concrete, art for people's sake meant that Black aesthetics should focus on the everyday social and political lives of Black people. He touches on the psychological implications regarding the purpose for Black art. He states "Black art will elevate and enlighten our people and lead them toward awareness of self, i.e., their Blackness" (5). Madhubuti's perspective advocates a Black art work that is openly and purposefully political. He further says that "Black poetry will be political and asserted that — there is no neutral Black art" (16). This statement adds an important layer to the project of defining Black aesthetics and binds the connection between socially just acts, politics, and art.

Since the 1970s, Black aesthetics has moved to include form and analysis, Afro- centricism, post- structural concepts, Black feminist perspectives, and the interconnected complexity between hip-hop philosophy, culture, and rap music. Hip-hop has emerged as a dominant form of the popular culture of blacks in America that includes music genres, rap, and rhythm-and-blues. The movement of hip-hop culture has played an important role in shaping African-Americans through music, videos, and dance. It has served as an outlet for African-Americans to articulate the problems they have in living in a racist society of 
America. Through rhythm and poetry, hip-hop has addressed racism, education, sexism, drug use, and spiritual uplift. Carolyn Fowler discusses on the utility and notion of Black form and focuses her attention on characterizing some of the salient features of Black art that may be consistent in all arts media. She points out the notion of balance rather than symmetry, the core concept of the Euro American tradition as the central concept: "Balance is knowing how far to go and still get back; how far to bend over in the dance without falling, how long to draw out a note without losing musicality, how far to take an improvisation without losing the theme" (16). Fowler reveals that balance comes with knowing how to dress extravagantly, mixing bold colors and many patterns. She gives an analysis of the taken-for-granted ordinary events in Black American life.

Winston Napier, creates a space to critique the philosophy that sustained the Black aesthetic. He argues that, "for a growing number of Black intellectuals, the critical era, also known as the Nationalists movement, was too focused on ideological platforms and establishing political agendas" (2000). Houston Baker's The Journey Back: Issues in Black Literature and Criticism is an important critique on the developmental issue of Black aesthetics, putting forth his stance on Black art and Black aesthetic movement, he says, "Our stance was nationalistic; . . . The familiar terms were Black aesthetic, Black Power, and Nation Time. If this working vocabulary was limited, so too, was our perspective. We assumed we were fighting for survival, and we took Malcolm X's words quite literally: we proceeded by any means necessary" (11).

Larry Neal shifted from Black Nationalist philosophy toward structuralism theories to explore what he understood to be systematic elements of Black America's expressive culture. He asserts that "a main tenet of Black Power is the necessity for Black people to define the world in their own terms and that the Black artist has made the same point in the context of aesthetics" (23).

Maulana Karenga suggests that Black aesthetics can be defined as a "distinctive mode of artistic expression judged in terms of its creativity and beauty as well as its social relevance" (395). He advances a notion of Black cultural nationalism in the community. $\mathrm{He}$ asserts that "Black art had to be - functional, collective, and committed to be considered real and relevant" (412). For Karenga, functional art must self-consciously have and urge social purpose. He asserts that "Black art must respond positively to the reality of revolution and that it is very important that art plays a role in Black survival and not bog itself down in meaningless madness of the Western world wasted" (414). Karenga explains that " Black art must be functional, collective, and committing and 
dismissed the idea of —art for art's sake claiming — there is no such thing as art for art's sake. And all art reflects the value system from which it comes" (396). For Karenga, art does not "exist in the abstract just as freedom does not exist in the abstract. However, Black art must be an aesthetic translation of our will and struggle for liberation and a higher level of life" (395).

Molefi Asante develops a philosophical concept of Afro- centricity, which he defines as "the standpoint of the agency of African people and the centrality of Africa in its own story" (3). Asante's work and theory made an impact on public schools. Afrocentric aesthetic directly links the socio-political to the idea of social justice.

Another dimension added to Black aesthetics is Black feminist theory. Toni Cade articulates a feminist thought that argues "in a capitalist society a man is expected to be an aggressive, uncompromising, factual, lusty, intelligent provider of goods, and the woman, a retiring, gracious, emotional, intuitive, attractive consumer of goods" (The Sea Birds 44). In Gorilla, My Love, she says that, "the idea of community is a thread that connects the stories in the collection" (53). Bambara's works show her concern with how the wisdom of the community passes from generation to generation or how community manifests itself in the living. In Black Women Writers at Work, Bambara characterized Gorilla as "on the -block-, in the neighborhood, back glances pieces" (qtd. in Tate 24) that grew out of a concern for insuring space for children.

Other feminist perspectives include the works of Paule Marshall, June Jordan and Audre Lord. Paule Marshall's works examine the social and political struggles of Black immigrant communities as well as explore the themes of the coming of age, the quest for identity, and the centrality of women's voices. For example, in Brown Girl, Brownstones (1959), Black women are central to the story, which addresses the development of a teen-aged girl from an immigrant West Indian family. In the context of social and economic condition of 1930s and 1940s America, the significance of women's voices in the family as well as Black culture can be seen in the matriarch character Silla Boyce in Brown Girl. In other works, such as Soul Clap Hands and Sing (1961), Marshall examined American quest for materialism, racism, and exploitation as well as the intersection between African-American and African Caribbean cultures. Marshall continued to explore the complexities of constructing female identity within African-American and Caribbean cultures. She used the voices of her American Caribbean grandmothers to challenge conventional notions of gender as well as traditional cultural practices. 
Furthermore, a black feminist aesthetic in America can be seen in the work of Alice Walker, who focused on southern African-American women's voices. Her work demonstrates a commitment to exploring the lives of Black women, examining such social issues as the lives that could be viewed as restrictive and narrow and including women who were physically and psychologically abused, for example, the two main characters Margaret and Mem Copeland in the story The Third Life of Grange Copeland (1970). Walker challenged 1960s Black American cultural nationalist perspectives, which idealized Black manhood while rarely acknowledging the oppression of women. For example, her collection of poetry, Revolutionary Petunias (1973)articulated African American women's frustrations and resistance against injustice. Walker's narratives descriptively depicted women who suffered from communal alienation as well as characters who effectively persevered through oppression brought on by Black patriarchy as well as the oppression brought by White society in the narrative, for example, in The Color Purple (1982). The nuanced social and political views implicit in Walker's work serve to challenge the way people think about justice as well as create an aesthetic language through which to understand terms such as agency and social justice.

Smith says, "A Black feminist approach to literature that embodies the realization that the politics of sex as well the politics of race and class are crucially interlocking factors in the works of Black women writers is an absolute necessity" (132). In this passage, Smith suggested that Black feminist perspectives not only broaden the Black aesthetic project but also create an alternative language that reshapes the politics and tools used to perpetuate racism, classism, and patriarchy as well as the way people think about such ideas as social justice.

The 1980s and 1990s brought the works of Barbara Christian, Patricia Collins, and Joy James and further revealed moments in which Black feminists' thought informs the Black aesthetic. Black women theorists of this time engaged the issues of race, gender, politics, and sexuality as analytical tools to broaden the examination and interpretation of women's experiences. The work of these African-American women demonstrates that the incorporation of sexuality and gender expands the analytical tools of politics, race, and action already present in Black aesthetics. Black feminist thought can encourage collective identity by offering Black women and Black aesthetics, more broadly conceived, a different or nuanced view of their world and social justice than that offered by the established order. The next generation of artist (1980s and 1990s), particularly in music, seemed to have succumbed to sexist and misogynistic qualities as well. 
Morrison examines the Black experience and, specifically, the Black female experience within the Black community. Her contributions have become the body of AfricanAmerican literature through both her fiction and critical essays. Her fictions largely focus on various problems faced by African-American women. They give clear understanding of black life, society and culture. It is best to sum up the worth of Morrison's works in her own words, she writes:

If anything I do in the way of writing novels (or whatever I write) isn't about village or the community or about you. Then it is not about anything. I am interested in indulging myself in some private, closed exercise of my imagination that fulfills only the obligation of my personal dreams which is to say yes, the work must be political... it seems to me that the best art is political and you ought to make it unquestionably political and irrevocably beautiful at the same time. (qtd. In Ifran 10)

Morrison presents the non-linear African-American socio-historical reality, where she shows effect and after effect of the history of slavery. Her works offer a fresh perspective on black life, their history and genealogy. Her major works are slavery and racism, and their psychological and social effects on the blacks over ages. Morrison's novels show the victimization of black people within context of racial social order. The themes of her novels reflect the sense of identity of a black person trying to recover his/her history and culture, which has so far been suppressed due to white narcissism.

The Bluest Eye makes a critique on racism and class stratification. The narrative depicts an adolescent black girl who is preoccupied with White standards of beauty. Ideas of beauty, particularly those that relate to racial characteristics, are a major theme in this narrative. For instance, the title The Bluest Eyes refers to the wish of the main character Pecola that her eyes would turn blue. Her social experience teaches her to revere the whiteness, and consequently, she views whiteness as beauty. Further, insults about appearance are often given in racial terms: a light skinned student named Maureen is given favoritism at school. There is an ongoing contrast between the world shown in the media (like the movies) to which Pauline (Pecolas's mother) escapes and the world where she is a servant, as is seen in Morrison's subtle construction of the narrative chapters. Most chapters' titles appear as extracts from an elementary school reading book, which generally presents a happy White family. This kind of family presentation is a direct contrast with Pecola's existence.

In Sula, Morrison explores the nature of friendship and critiques the perception that one should conform to the community's expectations. Morrison further challenges utopian concepts of social justice in Paradise (1998). In brief, this story might be understood 
as an examination of justice and agency, interpreting the process of social justice as communal. The Paradise narrative addresses issues of agency and the necessity for building coalition in an oppressive patriarchal society. This story further complicates the dominant liberal and modern conceptualizations of social justice, particularly in the wake of the Civil Rights Movement.

Black art movement concepts a Black discourse to craft a black meaning of the term social justice. Such narratives in Morrison's novel as The Bluest Eye, Sula, and Paradise illustrate that justice is understood as inseparable from socio-historical context, thereby highlighting social justice concepts as an aesthetic reflection of sociopolitical injustices historically experienced by blacks or any oppressed. This movement demands the transformation for freedom and a higher level of life of African Americans. It is the distinctive mode of repressed artistic expressions of entire black community, and is judged in terms of creativity, beauty and social relevance. This movement is an urge for social purpose to respond positively to the reality of revolution, and is important to know that art plays a vital role for social renovation.

\section{References}

Asante, Molefi (1980). Afrocentricity: The theory of social change. Amulefi,

Baker, Houston (1980). The journey back: Issues in Black literature and criticism. Chicago University Press.

Bambara, Toni Cade (1972). Gorilla, My Love. New York: Vintage Books.

--- (1996). “The Sea Birds are Still Alive.” African American Review, vol.30, no. 3,pp. 40-52.

Dubois, W. E. B (1926). "Criteria for Negro art”. The Crises: A Record of the Darker Race, vol. 32, pp. 295-29.

Evans, M (1984). Black Women Writers'Critical Evaluation. Doubleday.

Fowler, Carolyn (1981). Black arts and Black aesthetics. First World.

Fuller, H. The Black Aesthetic(1971). Ed. A. Gayle. New York University Press.

Gates, H. L. Jr., and N. McKay (1997). The Norton Anthology of African American Literature. Norton.

Ifran, Ayesha (2002). Toni Morrison’s Beloved. Asia Book Club.

Karenga, Maulana (1988). "Black studies and the problematic of paradigm: The 
philosophical dimension." Journal of Black Studies, pp.395-414.

Madhubuti, H.R (1969).Don't cry, scream. Third World Press.

Marshall, Paule 91959). Brown Girl Brownstone. Penguin Random House LLC.

... ( 1961). Clap Hands and Sing. Britannica.

Napier Winston (2000). African American literature theory: A reader. New York University.

Neal, Larry (1989). Vision of A Liberated Future; Black Arts Movement Writings. Basic Books.

Smith, Barbara (1977). "Toward a Black Feminist Criticism". Conditions, vol. 2, no.1, pp. 27-43.

Tate, C (1983). Black Women Writers at Work. Continuum

Walker, Alice (1970). Revolutionary Petunias. kindle Store.

... (1982). The Color Purple. Harcourt Brace.

... (1970). The Third Life of Grange Copeland. Harcourt Brace. 